Canadian University Music Review

Revue de musique des universités canadiennes

\title{
John Beckwith and Frederick Hall, eds., Musical Canada: Words and Music Honouring Helmut Kallmann. Toronto: University of Toronto Press, 1988, 369 pp.
}

\section{Gordana Lazarevich}

Volume 9, numéro 2, 1989

URI : https://id.erudit.org/iderudit/1014911ar

DOI : https://doi.org/10.7202/1014911ar

Aller au sommaire du numéro

\section{Éditeur(s)}

Canadian University Music Society / Société de musique des universités canadiennes

\section{ISSN}

0710-0353 (imprimé)

2291-2436 (numérique)

Découvrir la revue

Citer ce compte rendu

Lazarevich, G. (1989). Compte rendu de [John Beckwith and Frederick Hall, eds., Musical Canada: Words and Music Honouring Helmut Kallmann. Toronto: University of Toronto Press, 1988, 369 pp.] Canadian University Music Review / Revue de musique des universités canadiennes, 9(2), 151-156.

https://doi.org/10.7202/1014911ar

All Rights Reserved (C Canadian University Music Society / Société de musique des universités canadiennes, 1989
Ce document est protégé par la loi sur le droit d'auteur. L’utilisation des services d'Érudit (y compris la reproduction) est assujettie à sa politique d'utilisation que vous pouvez consulter en ligne.

https://apropos.erudit.org/fr/usagers/politique-dutilisation/ 
1984 : 'Jean Girard : premier musicien professionnel de Montréal?', Cahiers de l'ARMuQ, 3: 23-33.

GALLAT-MORIN, E. et BOUCHARD, Antione.

1981 : 'Témoins de la vie musicale en Nouvelle-France' (catalogue de l'exposition du même nom tenue, en 1981, à la Faculté de musique de l'Université McGill, puis, en 1983, au Musée McCord de Montréal). Archives nationales du Québec, Ministère des Affaires culturelles.

GALLAT-MORIN, E. et GILBERT, Kenneth.

1985 : Le Livre d'orgue de Montréal, édition critique moderne, volumes 1 et 2 (le volume 3 paraîtra vientôt). St-Hyacinthe : Éditions Jacques Ostiguy.

JOHN BECKWITH and FREDERICK HALL, eds., Musical Canada: Words and Music Honouring Helmut Kallmann. Toronto: University of Toronto Press, $1988,369 \mathrm{pp}$.

This volume represents a Festschrift, or a garland of articles honouring Helmut Kallmann in recognition of his achievements during more than four decades devoted to studies of music in Canada. Librarian, then supervisor of the CBC Toronto Music Library, and finally, chief of the music division of the National Library in Ottawa, Kallmann's interest in the musical past of his adopted country led him into pioneering work in the field of musical culture.

His publications, listed in this volume in their entirety, include well over one hundred items. They attest to the rich scope of his interests which range from music in pre-20th-century Canada, cultural developments, biographies of individual musical personalities, to reviews, chronologies, and bibliographies. $\mathrm{He}$ has contributed extensively to national and international encyclopedias such as Musik in Geschichte und Gegenwart and the Encyclopedia of Music in Canada, in the process of disseminating information about Canadian musical achievements across the world.

Dr. Kallmann's book, A History of Music in Canada 1534-1914 (University of Toronto Press, 1960) was the first of its kind, and still serves today as the most comprehensive source on the topic. One of the editors of the monumental and pioneering Encyclopedia of Music in Canada, he is also on the board of directors of the Canadian Musical Heritage Society.

It is to the credit of the University of Toronto Press and the book's co-editors John Beckwith and Frederick Hall that they have taken the initiative to honour this prominent Canadian by means of a book which documents for 
posterity not only Dr. Kallmann's legacy, but also the rich musical traditions of our young country.

The 23 contributors represent varying fields of activity on today's musical scene: librarians, composers, research scholars and administrators, $\mathrm{CBC}$ and Radio Canada International writers and commentators, a music critic, and people currently or formerly associated with such major institutions as universities, the Canadian Musical Heritage Society, the Canadian Music Centre, and the Canadian Music Publisher's Association. The book constitutes fascinating reading, and the breadth and scope of the articles successfully reflect the variety and range of Dr. Kallmann's own scholarly activities and interests.

The volume includes articles in both official languages, as well as four compositions dedicated to him. Among the latter, Clifford Ford's 'A Little Fantasy on J.P. Clarke's Ballad Summer and Winter', Richard Johnston's 'Hommage to Helmut,' and John Weinzweig's 'CanOn Stride,' all written in 1986 specifically for the occasion, are pieces for the piano, Dr. Kallmann's own instrument, which is very close to his heart. The fourth composition, 'Sun-Father Sky-Mother,' by R. Murray Schafer, for solo voice, was completed in 1985 and is intended, according to the composer, for eventual incorporation into And Wolf Shall Inherit the Moon.

It is easy to lose oneself in the fascinating content of the various articles of this volume which could well function as a reader for courses on music in Canada, as well as an overview of aspects of this country's musical culture from the 17 th century to the present decade.

Such topics as early music education, regional music making in Toronto, Montreal, Ottawa, Halifax, and Victoria, transmission of aspects of European musical culture, dissemination of Canadian music through printing, biographical and analytical essays, a historical survey of the Canadian Music Council, commissioning of Canadian works by the CBC, and a critical overview of six outstanding discs offer a compound view into this country's musical achievements. The book presents an evolutionary view of music from its transmission by Christian missionaries and its transplanted European origins, through the social impact of amateur music making, the emergence of outstanding musical personalities, and finally, the development and growth of institutions for the propagation and preservation of our musical culture.

While it is understandable that a volume of this kind cannot be all-inclusive and needs to be selective in its topics, one still feels that the areas of Native and folk music are weakly represented, particularly in light of the work in the field of folk music by such people as Sir Ernest MacMillan, Marius Barbeau, and Helen Creighton. Beverley Cavanagh's article on Algonkian Indian hymns is, therefore, doubly welcome. In a lucid and well-documented essay, Dr. Cavanagh contradicts the belief that Native hymn singing was directed and controlled by Christian missionaries, by showing that until the mid-twentieth century the Algonkian Indians practiced the hymn tradition internally among themselves, without the aid of a priest and outside the context of the Mass. 
She also points out that the transmission of hymns had both oral and written aspects subjected to local variants of language and music.

The musical activities of the early missionaries are further articulated by Erich Schwandt in his article 'Musique Spirituelle (1718): Canada's First Music Manual,'. He points out that the Ursuline nuns of the late 17th and early 18 th century acted not only as healers of the sick and spokeswomen for Christianity, but as upholders of culture in a country which, at the time, still consisted predominantly of unsettled wilderness. The earliest treatise on the theory and practice of music to have been written in North America was primarily used by the nuns for their own edification.

That the Canadian musical tradition is built upon transplanted European culture becomes clearly evident in Claude Beaudry's listing of musical sources printed before 1800 and located in the library of Laval University. Two types of sources are included in this catalogue arranged in chronological order: early Canadian printed music, such as antiphonaries, graduals, and treatises, and transplanted European music such as arrangements of Haydn's symphonies, music by Pleyel, Clementi, Campra and others, so popular in the London and Paris amateur music-making society of the day.

Judging from the number of treatises on music printed in this country before 1800 , the process of music education seems to have been initiated early in this country's history. Lucien Poirier provides evidence that Jean-Jacques Rousseau's Le Dictionnaire de Musique (1764) was used for educational purposes in the Quebec seminary. He also points out that Joseph Quesnel's little comic work Colas et Colinette, the first of its kind to be composed in Canada, was modelled after and even parodied a musical number in Rousseau's intermezzo Le Devin du Village.

Gilles Potvin'a article on another Frenchman's connection with Canada, albeit a century-and-a-half later, Maurice Ravel's visit to Vancouver, Toronto, and Montreal in 1928 as part of his North-American tour, constitutes interesting reading. From the Canadian premiere of his Quartet in F minor by the Hart House String Quartet, to the varying press reviews of his performances of his own piano music, the article offers an insight into the composer's own thoughts on jazz and his contemporaries such as 'Les Six.' It is as much a portrait of Ravel's character as it is of the Canadian audiences whose reactions to the composer's music alternated from being scandalized (Vancouver) to judging it as being music without emotion (Toronto), to blatant ovations (Montreal). It would be of interest to find out about Ravel's reception in cities south of the border. Comparing audience reaction in New York, New Orleans, and St. Paul with that in Canada may reveal more about the degree of sophistication of Canadian audiences of the late 1920s.

The articles by Nancy Vogan, Carl Morey, Elaine Keillor, and Dale McIntosh recreate the flavour of regional music making in the 19th century. Vogan's historical overview of music instruction in Nova Scotia shows how early music education in Halifax owes its existence, in part, to military men who gave 
studio lessons in flute, violin, French horn, oboe and bassoon while awaiting to be called to action. This article, which is so rich in information that it would have been better served by either expansion to a monograph, or focus on a single issue, also touches upon the role of Protestant church music instruction and music education in schools.

Morey, Keillor, and McIntosh demonstrate that choral societies and military personnel also played an important function in Toronto, Ottawa, and Victoria. Bands provided music for ballroom dancing as well as concert performances of European repertoire in popular arrangements.

In a well-organized article Carl Morey not only discusses itinerant bands and the formation of a permanent orchestra in Toronto, but also documents the repertoire to which Toronto audiences were exposed, and the high quality of orchestral performances by visiting American orchestras. In his article, Dale McIntosh points out that due to Victoria's location as a maritime city, shops from the Royal Navy frequently dropped anchor in Esquimalt. Bands brought in on these ships considerably enhanced Victoria's musical life.

Canada's history is shaped by the genius of its men and women. The biographical notes on Sir Ernest Macmillan during his Ruhleben years, and on Violet Archer contribute glimpses into their artistic personalities. The four years spent in the Ruhleben camp as German prisoner of war provided Ernest Macmillan with a form of early musical training ground. His lectures and activities as actor, pianist, arranger, conductor, and composer received ample practice in this somewhat unexpected milieu in the middle of the first World War. The articles on MacMillan and Archer simply whet one's appetite for more information on both of these Canadian luminaries. Full-length monographs on each are long overdue. One looks forward to Keith MacMillan's forthcoming biography of his father.

Two articles in particular deal with the sponsorship, protection, and dissemination of Canadian music in the 20th century: Patricia Kellogg' discussion of 50 years of commissions by the CBC, and Ronald Napier's historical overview of the development and function of the Canadian Music Council. In her review of the number of compositions commissioned by the CBC since 1939, Kellogg presents some interesting statistics. A chart lists the breakdown of commissions by decade, type of work, and number of playing hours. The numbers that emerge from this study are impressive: premiere performances of 620 compositions by some 242 Canadian composers, resulting in a total of 10553 broadcast hours over the fifty years. Kellogg makes the point that the $\mathrm{CBC}$ has kept up its mandate and has 'made a unique effort to raise and maintain national awareness of the Canadian identity in music' (p. 258).

Despite the impressive figures, however, one wonders whether the CBC's commitment today is as ardent as it was in its earlier period with such strong supporters of Canadian music as Jean-Marie Beaudet, Geoffrey Waddington, John Adaskin, Samuel Hersenhoren, and John Peter Lee Roberts. At a talk to the Canadian Club in Ottawa on January 14, 1942, W.E. Gladstone 
Murray, General Manager of the CBC, summarized some of the action taken by the CBC to promote Canadian musical activities. This included performing simple songs as well as full-length compositions by more than 150 Canadian composers. He cites Jean Coulthard's 'Canadian Fantasy,' Robert Farnon's 'Symphonic Suite,' and compositions by Pol Morin as some examples of first radio performances.

Three years earlier, the CBC Programme Schedule for December 13, 1939 mentions 'Canadian Snapshots,' a series of 50 programmes, presented weekly on Wednesday nights featuring new works by Canadian composers. The first series to feature all Canadian works by such artists as Louis Applebaum, Hector Gratton, Eldon Rathburn, and Clermont Pepin, was conducted by Samuel Hersenhoren.

During the war years the $\mathrm{CBC}$ paid special attention to Canadian composers, and on December 28, 1941, the Programme Schedule cited, 'To the serious young composer of concert or symphonic music, an auditorium and orchestra of proportions suitable to the adequate performance of his works are rarely available. In Canada, a determined effort is being made to remedy this state of affairs. The CBC has assumed as a duty the seeking out and encouraging of exceptional creative talent in the field of musical composition.' Samuel Hersenhoren is mentioned again as being instrumental in seeking out young composers of outstanding ability.

In later years, John P.L. Roberts (first, Supervisor of Radio Music in Toronto, then Head of Radio Music for the entire English network), commissioned a number of works for the Centennial in 1967 and for World Music Week in 1975.

It is interesting to note that the Canadian Pacific Railway was one of the earliest corporations to sponsor music in Canada, particularly within the context of its folk art and folk music festivals from 1927 to 1931. Through John Murray Gibbon, head of publicity for the CPR, music was commissioned for a number of ballad operas. Healey Willan's music for such works as Prince Charlie and Flora (Banff, 1929), The Ayrshire Ploughman (Banff, 1930), and Indian Nativity Play (Victoria, 1929) was either composed or arranged especially for the occasion. It was at Gibbon's instigation that the CPR sponsored a competition in 1927 for musical compositions based on folk songs. The two winners who shared in the $\$ 3000$ prize were Sir Ernest Macmillan with his 'Six Bergerettes du Bas Canada' and Claude Champagne for 'Suite Canadienne.' 9

And finally, a number of articles such as F.R.C. Clarke's 'Healey Willan's Unfinished Requiem,' Walter Kemp's 'Three Masses by Maritime Composers,' and Istvan Anhalt's 'Thisness: Marks and Remarks,' discuss and

9 Gordana Lazarevich, The Musical World of Frances James and Murray Adaskin. (Toronto: University of Toronto Press, 1988), p. 14. 
analyze specific compositions. While all three skillfully approach the discussion of their specific works, Anhalt's article presents the reader with an insight into the composer's mind, witnessing the genesis and evolution of an idea. In this case it is the text to the Duo-drama cycle of songs 'Thisness.' The composer's own explanatory notes and text to the work, at times with Existentialist overtones, constitute an important commentary on his creative process.

The excellent collection of articles in Musical Canada should constitute standard reading fare for all artists concerned with their Canadian heritage.

Gordana Lazarevich

CLIFFORD, FORD, ed. The Canadian Musical Heritage/Le Patrimoine musical canadien: Sacred Choral Music II/Choeurs religieux et liturgiques II, Vol. 9, Ottawa: The Canadian Musical Heritage Society, 1988, xxviii, 279 pp.

The Canadian Musical Heritage Society continues its admirable series of publications devoted to Canadian music with a second volume devoted to religious works. This volume, edited by Clifford Ford, contains 46 examples of choral music drawn from the Protestant (mostly Anglican) and Roman Catholic traditions, and is restricted to anthems and canticles in English and Latin motets. The composers represented therein were active in the period from 1880 to 1920 . The society has plans for future volumes which will investigate this genre of music in the period after 1920 and will include works of greater magnitude, such as masses and Communion services.

There are many positive attributes to this edition. Most of the music has long been out-of-print, and its republication allows us to view Canadian church music coming of age during a time marked by controversy (as seen in the continued efforts of the Oxford Movement in the Church of England) and change (the Motu proprio of 1903 in the Roman Catholic church). Concurrent with this re-evaluation of the role of music in the worship service was the emergence of a thriving publishing industry in Canada, whose efforts in the field of religious music represent an important aspect of Canadian music publishing prior to 1920 . These, and many other topics relevant to the composition, performance and dissemination of sacred choral music in Canada, are discussed in the excellent introduction provided by the editor. Ford begins by defining the limitations of the volume, follows with a brief overview of the publishing trade in the era, and ends this section of the introduction with an investigation into the types of musical activity found in the Protestant and Roman Catholic churches of the time. The introduction concludes with critical notes which, in addition to the discussion of textual variants and other matters of musicological interest, provide publication data for each piece, locations of 